\title{
The genetic differences between gallbladder and bile duct cancer cell lines
}

\author{
SOICHIRO SAITO ${ }^{1}$, MILA GHOSH ${ }^{2}$, KEIKO MORITA ${ }^{1}$, TAKASHI HIRANO ${ }^{1}$, \\ MASANAO MIWA ${ }^{3}$ and TAKESHI TODOROKI ${ }^{2}$ \\ ${ }^{1}$ Applied Gene Technology Research Group, Institute of Biological Resources and Function, National Institute of Advanced \\ Industrial Science and Technology, Tsukuba-shi 305-8566; ${ }^{2}$ Department of Surgery, Institute of Clinical Medicine, \\ University of Tsukuba, Tsukuba-shi 305-8575; ${ }^{3}$ Department of Bio-Science, Nagahama Institute of \\ Bio-Science and Technology, Nagahama-Shi 526-0829, Japan
}

Received May 12, 2006; Accepted July 11, 2006

\begin{abstract}
Biliary tract cancers carry dismal prognoses. It is commonly understood that chromosomal aberrations in cancer cells have prognostic and therapeutic implications. However, in biliary tract cancers the genetic changes have not yet been sufficiently studied. The aim of this study was to clarify the presence of mutations in specific chromosomal regions that are likely to harbor previously unknown genes with a significant role in the genesis of biliary tract cancer. The recently developed bacterial artificial chromosome (BAC) array comparative genomic hybridization (CGH) can facilitate detail analysis with high resolution and sensitivity. We applied this to 12 cancer cell lines of the gallbladder (GBC) and the bile duct (BDC) using a genome-wide scanning array. Cell line DNA was labeled with green colored Cy5 and reference DNA derived from normal human leucocytes was labeled with red colored $\mathrm{Cy} 3$. GBC, as well as BDC cell lines, have shown DNA copy number abnormalities (gain or loss). In each of the seven GBC cell lines, the DNA copy number was gained on $6 \mathrm{p} 21.32$ and was lost on 3p22.3, 3p14.2, 3p14.3, 4q13.1, 22q11.21, 22q11.23, respectively. In five BDC cell lines, there were DNA copy number gains on $7 \mathrm{p} 21.1,7 \mathrm{p} 21.2,17 \mathrm{q} 23.2,20 \mathrm{q} 13.2$ and losses were on 1p36.21, 4q25, 6q16.1, 18q21.31, 18q21.33, respectively. The largest region of gain was observed on 13q14.3-q21.32 $(\sim 11 \mathrm{Mb})$ and of loss on 18q12.2-q21.1 ( 15 Mb), respectively. Both GBC and BDC cell lines have DNA copy number abnormalities of gains and/or losses on every chromosome. We were able to determine the genetic differences between gallbladder and bile duct cancer cell lines. BAC
\end{abstract}

Correspondence to: Dr Takeshi Todoroki, Department of Surgery, Institute of Clinical Medicine, University of Tsukuba, Tsukuba-Shi 305-8575, Japan

E-mail: todoroki@mail2.accsnet.ne.jp

Key words: bacterial artificial chromosome array comparative genomic hybridization, biliary tract cancer, gallbladder cancer, bile duct cancer array CGH has a powerful potential application in the screening for DNA copy number abnormalities in cancer cell lines and tumors.

\section{Introduction}

Biliary tract (gallbladder and bile duct) cancers carry dismal prognoses. However, few studies exist in the literature regarding the genetic changes in gallbladder and bile duct cancers (1-4). We set out to investigate the genetic changes in biliary tract cancers by bacterial artificial chromosome (BAC) array comparative genomic hybridization (CGH) as an extension of our research conducted in previous studies $(5,6)$. The BAC array CGH was recently developed and is very efficient in identifying chromosomal loss regions, as well as gains, at the mega base level (7). We analyzed genomic changes in 7 gallbladder cancer cell lines and 5 bile duct cancer cell lines.

\section{Materials and methods}

Cell lines. As we have previously reported, TGBC1, TGBC2, TGBC14, TGBC24, TGBC44, Mz-ChA1, Mz-ChA2 (5) are gallbladder cancer (GBC) cell lines, and TGBC47, TGBC51, TBCN6 and KMBC are bile duct cancer (BDC) cell lines $(6,8,9)$. The cells were cultured in DMEM with $10 \%$ FBS, except the TBCN6 cells, which were cultured in RPMI with $10 \%$ FBS. Genomic DNA was extracted using the Genomic tip (Qiagen) according to the manufacturer's instructions.

DNA labeling for BAC array $C G H$. Test and gender-matched reference DNAs were labeled by random priming in $50 \mu \mathrm{l}$ reaction volumes containing $0.5 \mu \mathrm{g}$ of genomic DNA using an array kit (Macrogen). Briefly, a $21 \mu 1$ pre-mixture was prepared and added to $20 \mu \mathrm{l}$ of random primer solution (Invitrogen). After denaturing the DNA for $5 \mathrm{~min}$ at $100^{\circ} \mathrm{C}$, dNTPs mixture solution was added, leading to a final labeling reaction containing $0.2 \mathrm{mM}$ of dATP, $0.2 \mathrm{mM}$ of dGTP, $0.2 \mathrm{mM}$ of dTTP, $0.1 \mathrm{mM}$ of dCTP, $0.1 \mathrm{mM}$ of Cy3 or Cy5-dCTP (Perkin-Elmer) and $40 \mathrm{U}$ of Klenow fragment (Invitrogen). After labeling, unincorporated nucleotides 


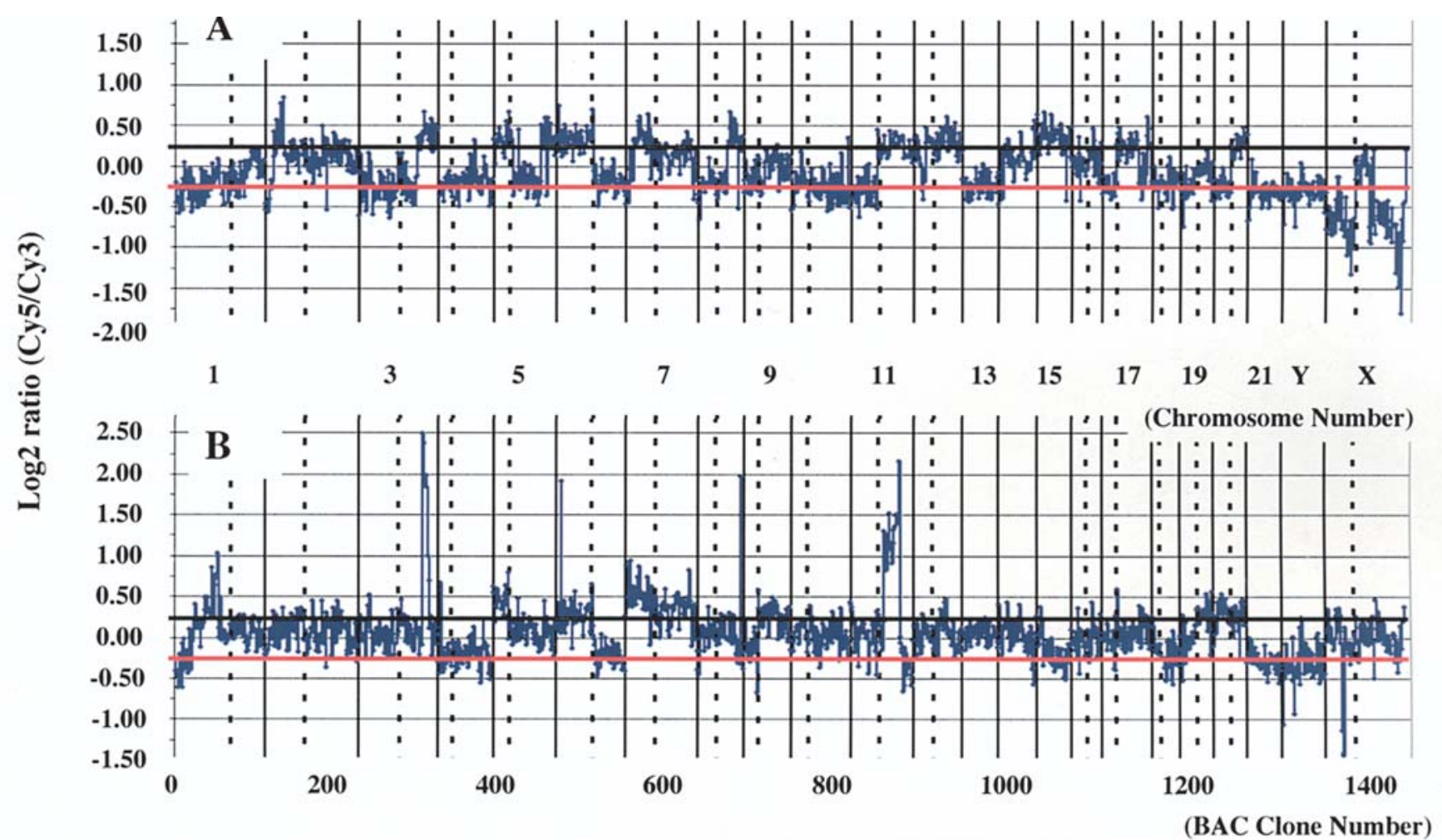

Figure 1. BAC array CGH profiles of gallbladder and bile duct cancer cells. The green line represents the cut-off level of the gain region and the red line represents the cut-off level of the loss region. BAC clones with a copy number ratio $>0.3$ were considered to be gained and those with a ratio $\leq 0.3$ were considered to be lost. The vertical solid line and dotted line represent the boundary and the centromere of each chromosome. (A) and (B) represent TGBC24 (gallbladder cancer) and TBCN6 (bile duct cancer) cell lines, respectively.

were removed by using the QIAquick PCR purification kit (Qiagen).

BAC array hybridization, imaging and data analysis. Labeled test and reference DNAs were mixed with solution B of the array kit (Macrogen) and ethanol-precipitation. The pellet was dissolved in $80 \mu \mathrm{l}$ of Solution $\mathrm{C}$ and $8 \mu \mathrm{l}$ of solution D. Probes were denatured for $5 \mathrm{~min}$ at $73^{\circ} \mathrm{C}$, and incubated at $37^{\circ} \mathrm{C}$ for 60 min to allow the blocking of repetitive sequences. The array slide was provided by Macrogen MAC Array ${ }^{\mathrm{TM}}$ KARYO 1,400 and pre-hybridized for $30 \mathrm{~min}$ at room temperature (RT). After two rinses of $10 \mathrm{sec}$ each in sterilized distilled water and isopropanol, the slides were dried by centrifugation. The hybridization-to-wash procedure was performed by Hybristation (Genomic Solutions) automatically. Briefly, hybridization was performed under a $22 \times 40 \mathrm{~mm}$ cover slip with incubation for $72 \mathrm{~h}$ at $37^{\circ} \mathrm{C}$. The slides were washed at $46^{\circ} \mathrm{C}$ for $15 \mathrm{~min}$ in $50 \%$ formamide and took turns at 2X SSC, 2 X SSC and $0.1 \%$ SDS at $46^{\circ} \mathrm{C}$ for $30 \mathrm{~min}$, PN buffer at RT for $15 \mathrm{~min}$, and finally $2 \mathrm{X} \mathrm{SSC}$ at RT for $5 \mathrm{~min}$. After washing, the slides were dehydrated by 70,85 , and $100 \%$ ethanol at RT for 1 min each, followed by centrifugation drying. The arrays were scanned using GenePix4000A (Axon Instrument). The Mac Viewer software (Macrogen) was used to locate spots automatically on the $\mathrm{Cy} 3$ and $\mathrm{Cy} 5$ image acquisitions and to calculate fluorescence ratios. The Mac Viewer software automatically analyzed and summarized the results as follows: (i) Averaged the ratios of the replicates and calculated the standard deviation, (ii) rejected individual spot data based upon several criteria (including weak fluorescent signals), (iii) adjusted the $\mathrm{Cy} 5 / \mathrm{Cy} 3$ ratios such that the ratios of the normal genomic regions were always equal to 0 , despite variations in dye labeling efficiency, and (iv) plotted data relative to the position of the clones on human genome (according to July 2003 UCSC cartography).

Statistical analysis. Significant difference comparisons of the frequencies of chromosomal imbalances between GBC cell line and BDC cell lines were assessed using two-sided Fisher's exact test. P-values $<0.05$ were considered significant, unless otherwise specified. Fisher's exact test was carried out with Stat View J software version 5 (SAS Institute).

\section{Results}

Gallbladder cancer cell lines. Different profiles of genomic copy-number abnormalities are demonstrated on various chromosomal regions in each of the GBC cell lines (Fig. 1A). All chromosomes in each of the seven GBC cell lines had DNA copy number abnormalities. Gain regions were on $1 p$, 1q, 2p, 2q, 3q, 4q, 5p, 5q, 6p, 6q, 7p, 7q, 8q, 11q, 12p, 12q, $16 \mathrm{q}, 17 \mathrm{q}, 19 \mathrm{q}, 20 \mathrm{q}$, and loss regions were on $1 \mathrm{p}, 3 \mathrm{p}, 3 \mathrm{q}, 4 \mathrm{p}$, 4q, 5q, 6q, 7q, 8p, 8q, 9p, 9q, 10p, 10q, 11p, 13q, 14q, 16p, $17 \mathrm{p}, 18 \mathrm{p}, 18 \mathrm{q}, 19 \mathrm{p}, 19 \mathrm{q}, 21 \mathrm{q}, 22 \mathrm{q}, \mathrm{Xp}, \mathrm{Xq}$, respectively. The frequent regional gain and loss loci (over 4 of 7 cell lines) are summarized in Table I. One gain region at $6 \mathrm{p} 21.32$ and six losses at 3p22.3, 3p14.2, 3p14.3, 4q13.1, 22q11.21 and $22 \mathrm{q} 11.23$ were detected in each of the seven GBC cell lines, respectively. Several known cancer-related genes ( $P B X 2$, 
Table I. Chromosomal regions demonstrating DNA copy number abnormalities in seven GBC cell lines.

\begin{tabular}{|c|c|}
\hline Gain & Loss \\
\hline $1 \mathrm{p} 21.3, \underline{1 q} 21.1,1 q 21.2-1 q 21.3,1 \mathrm{q} 23.3,1 \mathrm{q} 24.1,1 \mathrm{q} 31.1$ & 1p36.32-p36.33, 1p36.21, 1p34.3, 1p33-p34.2 \\
\hline 2p24.1, 2p23.2-p23.3, 2p22.1-p23.1 & $3 \mathrm{p} 26.3,3 \mathrm{p} 25.1,{ }^{\mathrm{a} 3 \mathrm{p} 22.3,3 \mathrm{p} 21.31-\mathrm{p} 22.1}$ \\
\hline $2 \mathrm{p} 16.1,2 \mathrm{p} 12,2 \mathrm{p} 11.2,2 \mathrm{q} 22.1,2 \mathrm{q} 23.3$ & $\underline{3 \mathrm{p} 21.31}, 3 p 21.2, \underline{\mathrm{a}} \mathrm{p} 14.3, \underline{\mathrm{a}} \mathrm{p} 14.2$ \\
\hline $2 \mathrm{q} 32.2, \underline{2 q 33.1}, 2 \mathrm{q} 34$ & 3p14.1,3p13-p14., 3p12.3, 3q22.2, 3q23 \\
\hline $3 q 13.11,3 q 26.2,3 q 27.3, \underline{3 q 28}$ & $4 \mathrm{p} 15.33-\mathrm{p} 16.1,{ }^{\mathrm{a}} 4 \mathrm{q} 13.1, \underline{4 \mathrm{q} 13.3}, 4 \mathrm{q} 23$ \\
\hline $4 q 28.1$ & $\underline{4 q 25}, 4 q 31.3,4 q 35.1-q 35.2$ \\
\hline $5 \mathrm{p} 15.33,5 \mathrm{p} 15.1-\mathrm{p} 15.2,5 \mathrm{p} 13.2,5 \mathrm{p} 13.1$ & $5 q 13.1,5 q 31.1,5 q 33.3-q 34$ \\
\hline $5 \mathrm{p} 12,5 \mathrm{q} 14.2,5 \mathrm{q} 33.1,5 \mathrm{q} 33.3$ & $6 \mathrm{q} 15, \underline{6 \mathrm{q} 27}$ \\
\hline${ }^{a} 6 p 21.32,6 \mathrm{q} 11.1$ & $7 \mathrm{q} 36.3$ \\
\hline 7p21.1-p21.2, 7p15.3,7p14.3,7p13-p14.1, & $8 \mathrm{p} 23.2-\mathrm{p} 23.3,8 \mathrm{p} 21.3, \underline{8 \mathrm{q} 24.22}$ \\
\hline $7 \mathrm{p} 13,7 \mathrm{p} 11.2,7 \mathrm{q} 21.2,7 \mathrm{q} 21.3$ & $9 \mathrm{p} 22.2,9 \mathrm{p} 21.3,9 \mathrm{q} 21.13,9 \mathrm{q} 34.3$ \\
\hline $8 q 21.13,8 \mathrm{q} 23.1-\mathrm{q} 23.3,8 \mathrm{q} 24.21,8 \mathrm{q} 24.3$ & $10 \mathrm{p} 15.3, \underline{10 \mathrm{p} 13}, 10 \mathrm{q} 11.21-\mathrm{q} 11.23$ \\
\hline $11 q 13.3,11 \mathrm{q} 22.3$ & $10 \mathrm{q} 23.2,10 \mathrm{q} 24.33, \underline{10 \mathrm{q} 25.3}, 10 \mathrm{q} 26.13$ \\
\hline $12 \mathrm{p} 13.33,12 \mathrm{p} 13.32, \underline{12 \mathrm{p} 12.1}, \underline{12 \mathrm{q} 15}$ & $11 \mathrm{p} 15.5, \underline{11 \mathrm{p} 15.4}, 11 \mathrm{p} 15.2-\mathrm{p} 15.3, \underline{11 \mathrm{p} 13}, \underline{11 \mathrm{p} 11.2}$ \\
\hline $12 \mathrm{q} 21.1,12 \mathrm{q} 21.32$ & $\underline{13 q 12.3}, \underline{13 q 13.1-q 13.2}, 13 q 21.32$ \\
\hline $16 q 22.1$ & $\underline{14 q 11.2}, 14 q 22.3,14 q 32.33$ \\
\hline $17 q 11.2,17 \mathrm{q} 21.31,17 \mathrm{q} 23.2$ & 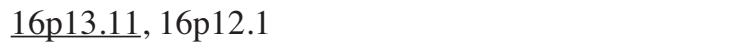 \\
\hline $19 q 13.32$ & $17 \mathrm{p} 12,17 \mathrm{p} 11.2$ \\
\hline \multirow[t]{8}{*}{$\underline{20 q 12}, 20 q 13.2,20 q 13.32,20 q 13.33$} & $18 \mathrm{p} 11.21,18 \mathrm{q} 12.1, \underline{18 \mathrm{q} 12.2-\mathrm{q} 21.1}$ \\
\hline & $18 \mathrm{q} 21.2-\mathrm{q} 21.31, \underline{18 \mathrm{q} 21.33}, 18 \mathrm{q} 21.33-\mathrm{q} 22.1,18 \mathrm{q} 23$ \\
\hline & $19 \mathrm{p} 13.3,19 \mathrm{q} 13.42$ \\
\hline & 21q21.1, 21q21.3, 21q22.11, 21q22.11-q22.12, \\
\hline & $21 \mathrm{q} 22.12,21 \mathrm{q} 22.13,21 \mathrm{q} 22-\mathrm{q} 22.3,21 \mathrm{q} 22.3$ \\
\hline & a22q11.21, a22q11.23, 22q12.1, 22q12.2, \\
\hline & $22 \mathrm{q} 12.3, \underline{22 \mathrm{q} 13.1}, 22 \mathrm{q} 13.31-\mathrm{q} 13.33$ \\
\hline & $\mathrm{Xp} 22.13, \underline{\mathrm{Xp} 11.3}, \mathrm{Xp} 11.23, \underline{\mathrm{Xq} 22.2}, \mathrm{Xq} 26.3, \underline{\mathrm{Xq} 28}$ \\
\hline
\end{tabular}

andicates chromosomal abnormality regions detected in each of the seven GBC cell lines. Underlining represents regions that showed DNA copy number abnormalities in more than half of the number of cell lines (both GBC and BDC).

ITGA9, Wnt-5a, BCR and RUTBC2) were located on the following chromosomal locations: $6 \mathrm{p} 21.32,3 \mathrm{p} 22.3,3 \mathrm{p} 14.3$, 22q11.21 and 22q11.23, respectively (Tables III and IV). In terms of the frequent gain regions, the known cancer-related genes are PDZK1 (1q21.1), ARNT (1q21.2-q21.3), CD48 (1q23.3), Tpr (1q31.1), KIAA0549 (2q33.1), FHF1 (3q28), RAD1, GDNF (5p13.2), SPARC (5q33.1), PBX2 (6p21.32), IL6 (7p15.3), GABS (7p11.2), IL7 (8q21.13), BCL1/CCND1 (1q13.3), krag (12p12.1), p53-associated (12q15), NF1 (17q11.2), BRCA1 (17q21.31), TBX2 (17q23.2), and TOP1 (20q12). In terms of the frequent loss regions, the known cancer-related genes are TGM4, IFRD2/ RASSF 1, HYAL1 (3p21.31), ACY1 (3p21.1), FHI1, PTPRG (3p14.2), Wnt5a (3p14.3), AFP (4q13.3), RGS (4q25), APC (5q33.3-q34), PDCD2 (6q27), NDRG1 (8q24.32), RSU1 (10p13), GFRA1 (10q25.3), ILK, STS, MRVI1 (11p15.4), WT1, LMO2, EHF (11p13), DDB2 (11p11.2), FLT1 (13q12.3), BRCA2 (13q13.1-q13.2), NRL (14q1.2), MRP (16p13.11), MBD, PCM1, DCC (18q12.2-q21.1), BCL2 (18q21.33), TIAMI (21q22.11), ISK/KCNE2 (21q22.11-q22.12), ETS2/E2 (21q22.1-q22.12), BCR (22q11.21), BAM22 (22q12.2),
PDGFB (22q13.1), NDP (Xp1.3), PLP (Xq22.2), TRAG3, and $X$ linked $A L D$ (Xq28). The largest, frequent gain was on chromosome $2 \mathrm{q} 32.2(\sim 5.1 \mathrm{Mb}$ in length); the largest loss was on $6 \mathrm{q} 15$ ( $\sim \mathrm{Mb}$ in length).

Bile duct cancer cell lines. Different profiles of genomic copy-number abnormalities are demonstrated on various chromosomal regions in each of the BDC lines (Fig. 1B). All the chromosomes in each of the five BDC cell lines had DNA copy number abnormalities. Gain regions were on $1 p$, 1q, 2p, 2q, 3p, 3q, 4q, 5p, 5q, 6p, 6q, 7p, 7q, 8q, 9q, 10q, $11 \mathrm{q}, 12 \mathrm{q}, 13 \mathrm{q}, 14 \mathrm{q}, 17 \mathrm{q}, 20 \mathrm{q}, 22 \mathrm{q}, \mathrm{Xq}, \mathrm{Yp}$ and loss regions were on 1p, 3p, 3q, 4q, 6p, 6q, 8q, 0p, 9q, 11p, 11q, 14q, 15q, $16 \mathrm{p}, 17 \mathrm{p}, 18 \mathrm{q}, 19 \mathrm{p}, 19 \mathrm{q}, 21 \mathrm{q}, 22 \mathrm{q}, \mathrm{Xp}, \mathrm{Xq}, \mathrm{Yq}$, respectively. Frequent regional gain and loss loci (loci involved in over 3 of 5 cell lines) are summarized in Table II. Four gain regions at $7 \mathrm{p} 21.1,7 \mathrm{p} 21.2,17 \mathrm{q} 23.3,20 \mathrm{q} 13.2$ and five loss regions at $1 \mathrm{p} 36.21,4 \mathrm{q} 25,6 \mathrm{q} 16.1,18 \mathrm{q} 21.31$, and $18 \mathrm{q} 21.33$ were detected in each BDC cell line, respectively. Several known cancer-related genes as HDAC9, Gax, TBX2, DOK5, $N E D D 4 L$ and $B C L 2$ were located on the following 
Table II. Chromosomal regions demonstrating DNA copy number abnormalities in five BDC cell lines.

\begin{tabular}{|c|c|}
\hline Gain & Loss \\
\hline 1p21.3, 1q24.1, 1q25.2, 1q31.1 & $1 \mathrm{p} 36.33,1 \mathrm{p} 36.32,{ }^{\mathrm{a}} 1 \mathrm{p} 36.21,1 \mathrm{p} 36.12$ \\
\hline $2 \mathrm{p} 16.1,2 \mathrm{p} 12,2 \mathrm{q} 23.3,2 \mathrm{q} 33.1,2 \mathrm{q} 33.3$ & $1 \mathrm{p} 36.11-1 \mathrm{p} 35.3,1 \mathrm{p} 33$ \\
\hline$\underline{3 p 21.1}, 3 q 13.11$ & $3 \mathrm{p} 26.3,3 \mathrm{p} 25.3,3 \mathrm{p} 25.1,3 \mathrm{p} 22.3,3 \mathrm{p} 21.33-\mathrm{p} 22.1$ \\
\hline$\underline{4 \mathrm{q} 12}$ & $\underline{3 p 21.31}, \underline{3 p 21.1}, \underline{3 p 14.3}, 3 \mathrm{p} 14.2$ \\
\hline 5p15.33, 5p15.2, 5p14.1-p15.1, 5p13.2, & $3 \mathrm{p} 14.1,3 \mathrm{p} 13-\mathrm{p} 14.1, \underline{\mathrm{qq} 28}$ \\
\hline $5 \mathrm{p} 12-\mathrm{p} 13.1,5 \mathrm{q} 14.2$ & $4 q 21.23,4 q 22.1,4 q 23, a 4 q 25, \underline{4 q 25-q 26}$ \\
\hline $6 \mathrm{p} 21.32,6 \mathrm{q} 11.1$ & $6 \mathrm{p} 25.2-\mathrm{p} 25.3,6 \mathrm{p} 21.33,6 \mathrm{q} 15-\mathrm{q} 16.1$ \\
\hline ap21.1-p21.2, 7p14.3, 7p13-p14.1,7p13, & $* 6 q 16.16 q 23.2, \underline{6 q 23.3}, 6 q 24.1,6 q 25.1, \underline{6 q 26-q 27}$ \\
\hline 7p11.2, 7q21.12, 7q21.2, 7q21.3, 7q31.2 & $8 \mathrm{p} 23.3$ \\
\hline 7q32.1, 7q32.3, 7q33, 7q34, 7q35 & $9 q 12$ \\
\hline $8 \mathrm{q} 21.3,8 \mathrm{q} 23.1-\mathrm{q} 23.3$ & $11 \mathrm{p} 15.5,11 \mathrm{p} 15.4,11 \mathrm{p} 11.2,11 \mathrm{q} 23.1-11 \mathrm{q} 23.2$ \\
\hline 9q21.11,9q33.1 & $14 q 32.33$ \\
\hline 10q26.13 & $15 q 25.2$ \\
\hline $11 q 14.2$ & $\underline{16 p 13.11}$ \\
\hline $12 \mathrm{q} 21.1$ & $\underline{17 \mathrm{p} 13.3}, 17 \mathrm{p} 13.2,17 \mathrm{p} 13.1, \underline{17 \mathrm{p} 11.2-\mathrm{p} 13.1}$ \\
\hline 13q13.1, 13q13.2-q14.11, 13q14.13, 13q14.3, & 18q12.2-q21.1, 18q21.1, ${ }^{\mathrm{a}} 18 \mathrm{q} 21.31$ \\
\hline 13q14.3-q21.32, 13q21.33, 13q22.2-q22.3, & $\underline{18 \mathrm{q} 21.31-\mathrm{q} 21.33},{ }^{\mathrm{a}} 18 \mathrm{q} 21.33,18 \mathrm{q} 23$ \\
\hline $13 q 32.1, \underline{13 q 33.1-q 34}$ & $19 \mathrm{p} 13.3, \underline{19 \mathrm{p} 13.2}, \underline{19 \mathrm{q} 13.42}$ \\
\hline $14 q 31.1$ & $\underline{21 q 22.11-q 22.12}, 21 \mathrm{q} 22.13, \underline{21 q 22.2-q 22.3}$ \\
\hline$\underline{17 q 11.2}, \underline{17 q 12}, 17 q 21.2, \underline{17 q 22},{ }^{\mathrm{a}} \underline{17 q 23.2}$ & $21 \mathrm{q} 22.3,21 \mathrm{q} 22.3,21 \mathrm{q} 22.3$ \\
\hline $20 \mathrm{p} 12.3,20 \mathrm{p} 12.1, \underline{\underline{a}} \underline{\underline{2} \mathrm{q} 13.2}$ & $\underline{22 q 11.21}, \underline{22 q 11.22-q 11.23}, 22 q 11.23,22 q 12.1,22 q 12.1-q 12.2$, \\
\hline $22 \mathrm{q} 11.21$ & $\underline{22 q 12.2}, 22 q 12.3,22 q 13.1, \underline{22 q 13.1}, 22 q 13.31, \underline{22 q 13.33}$ \\
\hline $\mathrm{Xq} 25$ & $\mathrm{Xp} 11.23, \mathrm{Xp} 11.21, \mathrm{Xq} 28$ \\
\hline Yp11.31 & $\underline{\mathrm{Yq} 11.223}, \underline{\mathrm{Yq} 11.23}$ \\
\hline
\end{tabular}

andicates common chromosomal abnormality regions detected in each of the 5 BDC cell lines. Underlining represents regions that showed DNA copy number abnormalities in more than half of the cell lines (both GBC and BDC).

chromosomal regions: 7p21.1, 7p21.2, 17q23.3, 20q13.2, $18 \mathrm{q} 21.31$, and 18q21.33, respectively (Tables III and IV). In terms of the frequent gain regions, known cancer-related genes are $T p r(1 \mathrm{q} 31.1)$, KIAA0549 (2q33.1), III7BR (3p21.1), KDR (4q12), GDNF (5p13.2), PBX2 (6p21.32), MET (7q31.2), DACH (13q21.33), EDNRB (13q22.2-q22.3), ERCC5 (13q33.1-q34), TSHR (14q31.1), NF1 (17q11.2), HER2, ERBB2 (17q12), HLF (17q22), and TBX2 (17q23.3). On the frequent loss regions, known cancer-related genes are CDC2L1 (1p36.33), p73 (1p36.32), FGR (1p36.11-p35.3), LMCD1 (3p25.3), LFRD2/RSSF1, HYAL1 (3p21.31), BAP1 (3p21.1), Wht5a (3p14.3), LPP (3q28), RGS (4q25-q26), IRF4 (6p25.2-p25.3), HLA-B (6p21.33), MYB (6q23.3), PDCD2 (6q26-q27), DDB2 (11p15.4), MRP (16p13.1), LISI (17p13.3), MBD, PCM1, DCC (18q21.1), BCL2 (18q21.31q21.33), ICAM1 (19p13.2), ISK/KCNE2 (21q22.11-q22.12), ETS2/E2 (21q22.2-q22.3), BCR (22q11.21), BCR-ABL, $R A B 36$ (22q11.22-q11.23), EVS, BAM2 (22q12.2), PDGFB (22q13.1), ECGF1 (22q13.33), YRRM2 (Yq11.223), and CDY1 (Yq11.23).

The largest, frequent gain was on chromosome 13q14.3q21.32 ( $11 \mathrm{Mb}$ in length); the largest loss was on 18q12.2q21.1 ( $\sim 15 \mathrm{Mb}$ in length). Chromosome numbers 12,13 and
21 displayed DNA copy number abnormalities in each chromosomal region (data not shown).

Unique candidate genes related to biliary tract cancer cells. We tried to determine the genes that were related to malignancy uniquely in $\mathrm{GBC}$ and $\mathrm{BDC}$ by comparing the incidence of DNA copy number abnormalities in each chromosomal region. In the BDC cell lines, the candidate genes, $N A 4 B$ on the locus $7 \mathrm{q} 32.3$ and SEC $8 L 1$ on the locus $7 \mathrm{q} 33$, were extracted by their significant DNA copy number gain. In the GBC cell lines, SAMD10 and SOX18 on the locus 20q13.33 were nominated as unique cancer-related genes based upon gains in the DNA copy number, whereas, ROBO1 on $3 \mathrm{p} 12.3$ and ITK and CYFIP2 on $5 \mathrm{q} 33.3$ were unique candidate genes because they displayed significant losses of DNA copy number. Although the 4q13.1 locus showed a significant DNA copy number loss in the GBC cell lines, no cancer-related gene was identified (Table V).

\section{Discussion}

By our high resolution BAC array $\mathrm{CGH}$, loss regions were more precisely detected in this study than previous studies by 
Table III. The incidence of cell lines showing DNA copy number loss and the candidate cancer-related genes on individual chromosomal regions of GBC and BDC cell lines.

\begin{tabular}{|c|c|c|c|c|}
\hline \multirow[t]{2}{*}{ No. } & \multirow[t]{2}{*}{$\begin{array}{l}\text { Chromosomal } \\
\text { regions }\end{array}$} & \multicolumn{2}{|c|}{$\begin{array}{l}\text { Rate of abnormal DNA copy } \\
\text { number in each cell line }\end{array}$} & \multirow[t]{2}{*}{$\begin{array}{l}\text { Candidate cancer- } \\
\text { related gene }\end{array}$} \\
\hline & & $\operatorname{GBC}(n=7)$ & $\operatorname{BDC}(n=5)$ & \\
\hline 1 & $1 \mathrm{p} 36.21$ & $85.7 \%(6 / 7)$ & $100 \%(5 / 5)$ & \\
\hline 2 & $1 \mathrm{p} 34.1$ & $57.1 \%(4 / 7)$ & $0 \%$ & РТCH2 \\
\hline 3 & $3 \mathrm{p} 12.3$ & $85.7 \%(6 / 7)$ & $0 \%$ & \\
\hline 4 & $3 \mathrm{p} 14.2$ & $100 \%(7 / 7)$ & $80 \%(4 / 5)$ & FHIT, PTPRG \\
\hline 5 & $3 \mathrm{p} 14.3$ & $100 \%(7 / 7)$ & $60 \%(3 / 5)$ & $W n t 5 a$ \\
\hline 6 & $3 \mathrm{p} 22.3$ & $100 \%(7 / 7)$ & $60 \%(3 / 5)$ & ITGA9 \\
\hline 7 & $4 \mathrm{q} 13.1$ & $100 \%(7 / 7)$ & $40 \%(2 / 5)$ & \\
\hline 8 & $4 \mathrm{q} 25$ & $57.1 \%(4 / 7)$ & $100 \%(5 / 5)$ & \\
\hline 9 & $5 \mathrm{q} 31.1$ & $57.1 \%(4 / 7)$ & $0 \%$ & \\
\hline 10 & $5 \mathrm{q} 33.3$ & $57.1 \%(4 / 7)$ & $0 \%$ & \\
\hline 11 & $6 \mathrm{p} 21.33$ & $0 \%$ & $80 \%(4 / 5)$ & $H L A-B$ \\
\hline 12 & $6 \mathrm{q} 16.1$ & $42.9 \%(3 / 7)$ & $100 \%(5 / 5)$ & \\
\hline 13 & $6 \mathrm{q} 23.2$ & $0 \%$ & $60 \%(3 / 5)$ & \\
\hline 14 & $7 \mathrm{q} 36.3$ & $57.1 \%(4 / 7)$ & $0 \%$ & \\
\hline 15 & $9 \mathrm{p} 21.3$ & $57.1 \%(4 / 7)$ & $0 \%$ & \\
\hline 16 & $9 q 21.13$ & $57.1 \%(4 / 7)$ & $0 \%$ & \\
\hline 17 & $16 \mathrm{p} 12.1$ & $57.1 \%(4 / 7)$ & $0 \%$ & \\
\hline 18 & $18 \mathrm{q} 21.31$ & $71.4 \%(5 / 7)$ & $100 \%(5 / 5)$ & \\
\hline 19 & $18 \mathrm{q} 21.33$ & $85.7 \%(6 / 7)$ & $100 \%(5 / 5)$ & $B C L 2$ \\
\hline 20 & $22 \mathrm{q} 11.21$ & $100 \%(7 / 7)$ & $80 \%(4 / 5)$ & $B C R$ \\
\hline 21 & $22 q 11.23$ & $100 \%(7 / 7)$ & $80 \%(4 / 5)$ & RUTBC2 \\
\hline
\end{tabular}

Table IV. The incidence of cell lines showing DNA copy number gain and the candidate cancer-related genes on the individual chromosomal regions of GBC and BDC cell lines.

\begin{tabular}{|c|c|c|c|c|}
\hline \multirow[t]{2}{*}{ No. } & \multirow[t]{2}{*}{$\begin{array}{l}\text { Chromosomal } \\
\text { regions }\end{array}$} & \multicolumn{2}{|c|}{$\begin{array}{l}\text { Rate of abnormal DNA copy } \\
\text { number in each cell line }\end{array}$} & \multirow[t]{2}{*}{$\begin{array}{l}\text { Candidate cancer- } \\
\text { related gene }\end{array}$} \\
\hline & & GBC $(n=7)$ & $\mathrm{BDC}(\mathrm{n}=5)$ & \\
\hline 1 & 1Q21.1 & $57.1 \%(4 / 7)$ & $0 \%$ & $P D Z K 1$ \\
\hline 2 & 1Q21.2-Q21.3 & $57.1 \%(4 / 7)$ & $0 \%$ & $A R N T$ \\
\hline 3 & $2 \mathrm{Q} 33.3$ & $0 \%$ & $60 \%(3 / 5)$ & \\
\hline 4 & 3Q28 & $57.1 \%(4 / 7)$ & $0 \%$ & \\
\hline 5 & $3 \mathrm{Q} 28$ & $57.1 \%(4 / 7)$ & $0 \%$ & \\
\hline 6 & $3 \mathrm{Q} 28$ & $57.1 \%(4 / 7)$ & $0 \%$ & \\
\hline 7 & $3 \mathrm{Q} 28$ & $57.1 \%(4 / 7)$ & $0 \%$ & $F H F-1$ \\
\hline 8 & 4Q12 & $0 \%$ & $60 \%(3 / 5)$ & $K D R$ \\
\hline 9 & 4Q28.1 & $57.1 \%(4 / 7)$ & $0 \%$ & \\
\hline 10 & $6 \mathrm{P} 21.32$ & $100 \%(7 / 7)$ & $60 \%(3 / 5)$ & $P B X 2$ \\
\hline 11 & 7P21.1 & $57.1 \%(4 / 7)$ & $100 \%(5 / 5)$ & HDAC9 \\
\hline 12 & $7 \mathrm{P} 21.2$ & $85.7 \%(6 / 7)$ & $100 \%(5 / 5)$ & Gax \\
\hline 13 & 7P21.2 & $0 \%$ & $60 \%(3 / 5)$ & ETV1 \\
\hline 14 & 7Q32.3 & $0 \%$ & $80 \%(4 / 5)$ & \\
\hline 15 & $7 Q 33$ & $0 \%$ & $80 \%(4 / 5)$ & \\
\hline 16 & 7Q34 & $0 \%$ & $60 \%(3 / 5)$ & $T C R B$ \\
\hline 17 & 12P12.1 & $57.1 \%(4 / 7)$ & $0 \%$ & krag \\
\hline 18 & $13 Q 14.13$ & $0 \%$ & $60 \%(3 / 5)$ & \\
\hline 19 & $13 \mathrm{Q} 21.32$ & $0 \%$ & $60 \%(3 / 5)$ & \\
\hline 20 & 17Q23.3 & $85.7 \%(6 / 7)$ & $100 \%(5 / 5)$ & $T B X 2$ \\
\hline 21 & 20Q13.2 & $71.4 \%(5 / 7)$ & $100 \%(5 / 5)$ & DOK5 \\
\hline 22 & 20Q13.33 & $57.1 \%(4 / 7)$ & $0 \%$ & \\
\hline
\end{tabular}


Table V. Candidate genes related to malignancies unique in GBC/BDC.

\begin{tabular}{|c|c|c|c|c|c|c|}
\hline \multirow[t]{2}{*}{ No. } & \multirow[t]{2}{*}{ Region } & \multirow[t]{2}{*}{ Abnormality } & \multicolumn{2}{|c|}{ Incidence } & \multirow[t]{2}{*}{ P-value } & \multirow[t]{2}{*}{ Candidate gene (s) } \\
\hline & & & GBC & $\mathrm{BDC}$ & & \\
\hline 1 & $7 q 32.3$ & Gain & 0 & 4 & 0.0101 & $P L X N A 4 B$ \\
\hline 2 & $7 q 33$ & & 0 & 4 & 0.0101 & $S E C 8 L 1$ \\
\hline 3 & $20 q 13.33$ & & 5 & 0 & 0.0278 & SAMD10, SOX18 \\
\hline 4 & $3 \mathrm{p} 12.3$ & Loss & 6 & 0 & 0.0152 & ROBOI \\
\hline 5 & $4 q 13.1$ & & 7 & 2 & 0.0455 & \\
\hline 6 & $5 q 33.3$ & & 5 & 0 & 0.0278 & $I T K, C Y F I P 2$ \\
\hline
\end{tabular}

The p-value was obtained by Fisher's exact test.

conventional CGH $(5,6)$. In 21 chromosomal regions of either BDC or GBC cell lines, the DNA copy number loss was exhibited frequently (Table III). Regions 3p12.3 and 6 p21.33 should be noted in terms of unique DNA copy number loss. At region 3p12.3, six of the seven GBC cell lines showed a DNA copy number loss, although each of the 5 BDC cell lines did not show a DNA copy number loss. On the contrary, at region $6 \mathrm{p} 21.33$, the $7 \mathrm{GBC}$ cell lines did not show a DNA copy number loss, although four of the five BDC cell lines showed a DNA copy number loss (Table III).

In addition, 22 chromosomal regions demonstrated DNA copy number gains in either the BDC or GBC cell lines (Table IV). However, no cancer-related gene has been identified on $7 \mathrm{q} 32.3$ or $7 \mathrm{q} 33$ regions. Further studies on these gain regions might be significant for distinguishing $\mathrm{GBC}$ and BDC (Table IV).

Seven well-known cancer-related genes (PBX2, FHIT, $P T P R G, W n t 5 a, I T G A 9, B C R$ and RUTBC2) were detected in the seven gallbladder cell lines (Tables III and IV). The $P B X 2$ gene is located on $6 \mathrm{p} 21.32$ and encodes a homeodomain protein, which is a member of the three-amino-acid loop extension (TALE) family. PBX proteins interact with a number of Hox proteins. $P B X$ genes, including $P B X 2$, have an essential role in embryonic development (10). FHIT, PTPRG and Wnt5a genes are located on 3p14.2-p14.3. These regions have already been reported to display a loss of heterozygosity ( $\mathrm{LOH}$ ) in lung, esophageal, stomach and gallbladder cancers (11-14). On the $3 \mathrm{p} 22.3$ region, the ITGA9 gene encodes alpha integrin. We first found that this region was deleted commonly in gallbladder cancers, but we could not determine whether the deletion was homozygous or heterozygous as in renal, lung and breast cancers (15). The $B C R$ gene is located on the $22 \mathrm{q} 11.21$ region and this particular region is the site of translocation $t(9: 22)$ in chronic myelogenous leukemia (16). The RUTBC2 gene (one of the human proteome genes) (17) is located on the $22 q 11.23$ region. This locus often displays LOH or homozygous deletions in some pediatric rhabdoid tumors $(18,19)$, but the loss of this region in gallbladder cancers has not been reported.

In BDC, four well-known cancer-related genes (HDAC9, Gax, $T B X 2$, and DOK5) were detected in all five BDC cell lines (Tables III and IV). The HDAC9 gene is located on
$7 \mathrm{p} 21.1$ and is a member of the histone deacetylase family. It is known that this gene has alternative splicing variants to generate multiple protein isoforms that may play distinct biological roles and that this gene is associated with human cancer (20). The Gax gene is located on 7p21.2 and is one of the homeobox genes that is closely related to angiogenesis (21). The $T B X 2$ gene is located on $17 \mathrm{q} 23.3$ and this region is also the site of gains in many cancers (22-25). The TBX2 gene is a member of the T-Box transcription factors contributing to oncogenic transformation (26). The DOK5 gene is located on 20q13.2 and is a member of a downstream of tyrosine kinase family related to myeloid homeostasis and leukemia (27). We discovered a loss region (18q21.33), which encodes a well-known $B C L 2$ gene and this gene plays an anti-apoptotic role (28). However, on other loss regions (1p36.21, 4q25 and 6q16.1) commonly detected in all five BDC lines, no cancer-related gene was found (Tables III and IV).

In the statistical analysis, the significant gain genes were $P L X N A 4 B(7 \mathrm{q} 32.3, \mathrm{p}=0.0101)$ and SEC8L1 $(7 \mathrm{q} 33, \mathrm{p}=0.0101)$ in BDC. The PLXNA4B gene produces a protein product that is a member of the semaphorin family, and semaphorins are related to one of the axon guidance molecules (29). The SEC $8 L 1$ gene is a member of the $\sec 8$ gene that is related to the exocyst complex (30).

The significant gains in GBC were in the SAMD10 and SOX18 genes (20q13.33). The SAMD10 gene produces a protein product that has a sterile alpha motif domain which not only exhibits diverse protein-protein interactions but also has the ability to bind RNA, defining a new type of posttranscriptional modification gene (31). The SOX18 gene is one of the Sry-type high-mobility group box gene family, which encode transcription factors in diverse developmental processes, and the mutation of this gene is related to hypotrichosis-lymphedema-telangiectasia (32). On the contrary, the significant losses were only apparent in GBCL: ROBO1 (3p12.3, $\mathrm{p}=0.0278)$ and $I T K$ and CYFIP2 (5q33.3, $\mathrm{p}=0.0278$ ). The $R O B O 1$ gene, which encodes a member of the neural cell adhesion molecule family of receptors, was recently cloned from the lung cancer tumor suppressor gene region 2 , and resides in a region that has been the site of overlapping homozygous deletions characterized in both 
small cell lung cancer cell lines and in a breast cancer cell line (33). The ITK gene encodes a product that is a member of $\mathrm{T}$ cell-specific Tec family, plays a role in the maturation of thymocytes, is required for intracellular signaling following T cell receptor (TCR) crosslinking, and is involved in the generation of second messengers that mediate cytoskeletal reorganization (34). The CYFIP2 gene encodes a protein that is a member of a highly conserved protein family and that is expressed mainly in brain tissue, white blood cells and the kidney. The CYFIP2 is a $p 53$-inducible protein, thus, possibly a pro-apoptotic gene (35). Although the $4 \mathrm{q} 13.1$ locus was also the site of significant loss $(\mathrm{p}=0.0455)$ in $\mathrm{GBC}$, on this locus no cancer related gene has been identified.

Although DNA copy number abnormalities were observed in every chromosome, chromosomes 12, 13 and 21 demonstrated abnormalities of all the BAC clones in each chromosomal region. These observations suggest that chromosomes 12, 13 and 21, at least in part, might be linked to cancer developments and progression.

In conclusion, both GBC and BDC cell lines have DNA copy number abnormalities of gains and/or losses on every chromosome and we were able to determine the genetic differences between gallbladder and bile duct cancer cell lines using BAC array CGH. Therefore, BAC array CGH has potential application in the screening for DNA copy number abnormalities in cancer cell lines and tumors.

\section{References}

1. Arakawa A, Fujii H, Matsumoto T, Hirai S and Suda K: Loss of heterozygosity in clonal evolution with genetic progression and divergence in A spindle cell carcinoma of the gallbladder. Hum Pathol 35: 418-423, 2004.

2. Hidaka E, Yanagisawa A, Sakai Y, Seki M, Kitagawa T, Setoguchi $\mathrm{T}$ and Kato $\mathrm{Y}$ : Losses of heterozygosity on chromosomes $17 \mathrm{p}$ and $9 \mathrm{p} / 18 \mathrm{q}$ may play important roles in early and advanced phases of gallbladder carcinogenesis. J Cancer Res Clin Oncol 125: 439-443, 1999.

3. Hidaka E, Yanagisawa A, Seki M, Setoguchi T and Kato Y: Genetic alterations and growth pattern in biliary duct carcinomas: loss of heterozygosity at chromosome $5 \mathrm{q}$ bears a close relation with polypoid growth. Gut 48: 656-659, 2001.

4. Kim Y, Kim J, Jang Y, Lee W, Ryu J, Park Y, Kim S, Kim W, Yoon Y and Kim C: Genetic alterations in gallbladder adenoma, dysplasia and carcinoma. Cancer Lett 169: 59-68, 2001.

5. Ghosh M, Koike N, Tsunoda S, Kaul S, Hirano T, Kashiwagi H, Kawamoto T, Ohkohchi N, Saijo K, Ohno T, Miwa M and Todoroki T: Characterization and genetic analysis in the newly established human unique bile duct cancer cell lines. Int J Oncol 26: 449-456, 2005.

6. Ghosh M, Koike N, Yanagimoto G, Tsunoda S, Kaul S, Hirano T, Emura F, Kashiwagi H, Kawamoto T, Ohkohchi N, Saijo K, Ohno T, Miwa M and Todoroki T: Establishment and characterisation of human unique gallbladder cancer cell lines. Int J Oncol 24: 1189-1196, 2004.

7. Pinkel D, Segraves R, Sudar D, Clark S, Poole I, Kowbel D, Collins C, Kuo WL, Chen C, Zhai Y, Dairkee SH, Ljung BM, Gray JW and Albertson DG: High-resolution analysis of DNA copy number variation using comparative genomic hybridization to microarrays. Nat Genet 20: 207-211, 1998

8. Knuth A, Gabbert H, Dippold W, Klein O, Sachsse W, BitterSuermann D, Prellwitz W and Meyer zum Buschenfelde K: Biliary adenocarcinoma. Characterisation of three new human tumor cell lines. J Hepatol 1: 579-596, 1985.

9. Yano H, Maruiwa M, Iemura A, Mizoguchi A and Kojiro M: Establishment and characterization of a new human extrahepatic bile duct carcinoma cell line (KMBC). Cancer 69: 1664-1673, 1992.
10. Longobardi E and Blasi F: Overexpression of PREP-1 in F9 teratocarcinoma cells leads to a functionally relevant increase of PBX-2 by preventing its degradation. J Biol Chem 278: 39235-39241, 2003.

11. Wang J, Cheng YW, Wu DW, Chen JT, Chen CY, Chou MC and Lee H: Frequent FHIT gene loss of heterozygosity in human papillomavirus-infected non-smoking female lung cancer in Taiwan. Cancer Lett 235: 18-25, 2006.

12. Cheung AL, Si HX, Wang LD, An JY and Tsao SW: Loss of heterozygosity analyses of esophageal squamous cell carcinoma and precursor lesions from a high incidence area in China. Cancer Lett (In press).

13. Huiping C, Kristjansdottir S, Bergthorsson JT, Jonasson JG, Magnusson J, Egilsson V and Ingvarsson S: High frequency of LOH, MSI and abnormal expression of FHIT in gastric cancer. Eur J Cancer 38: 728-735, 2002.

14. Wistuba II, Ashfag R, Maitra A, Alvarez H, Riquelme E and Gazdar AF: Fragile histidine triad gene abnormalities in the pathogenesis of gallbladder carcinoma. Am J Pathol 160: 2073-2079, 2002.

15. Senchenko VN, Liu J, Loginov W, Bazov I, Angeloni D, Seryogin Y, Ermilova V, Kazubskaya T, Garkavtseva R, Zabarovska VI, Kashuba VI, Kisselev LL, Minna JD, Lerman MI, Klein G, Braga EA and Zabarovsky ER: Discovery of frequent homozygous deletions in chromosome 3p21.3 LUCA and AP20 regions in renal, lung and breast carcinomas. Oncogene 23: $5719-5728,2004$

16. Chalandon Y and Schwaller J: Targeting mutated protein tyrosine kinases and their signaling pathways in hematologic malignancies. Haematologica 90: 949-968, 2005

17. Katoh M and Katoh M: Characterization of RUSC1 and RUSC2 genes in silico. Oncol Rep 12: 933-938, 2004.

18. Mori T, Fukuda Y, Kuroda H, Matsumura T, Ota S, Sugimoto T, Nakamura Y and Inazawa J: Cloning and characterization of a novel $R a b$-family gene, $R a b 36$, within the region at $22 \mathrm{q} 11.2$ that is homozygously deleted in malignant rhabdoid tumors. Biochem Biophys Res Commun 254: 594-600, 1999.

19. Zhou J, Fogelgren B, Wang Z, Roe BA and Biegel JA: Isolation of genes from the rhabdoid tumor deletion region in chromosome band 22q11.2. Gene 241: 133-141, 2000.

20. Petrie K, Guidez F, Howell L, Healy L, Waxman S, Greaves M and Zelent A: The histone deacetylase 9 gene encodes multiple protein isoforms. J Biol Chem 278: 16059-16072, 2003.

21. Patel S, Leal AD and Gorski DH: The homeobox gene Gax inhibits angiogenesis through inhibition of nuclear factorkappaB-dependent endothelial cell gene expression. Cancer Res 65: 1414-1424, 2005

22. Katoh H, Shibata T, Kokubu A, Ojima H, Loukopoulos P, Kanai Y, Kosuge T, Fukayama M, Kondo T, Sakamoto M, Hosoda F, Ohki M, Imoto I, Inazawa J and Hirohashi S: Genetic profile of hepatocellular carcinoma revealed by array-based comparative genomic hybridization: Identification of genetic indicators to predict patient outcome. J Hepatol 43: 863-874, 2005.

23. Mosse YP, Greshock J, Margolin A, Naylor T, Cole K, Khazi D, Hii G, Winter C, Shahzad S, Asziz MU, Biegel JA, Weber BL and Maris JM. High-resolution detection and mapping of genomic DNA alterations in neuroblastoma. Genes Chromosomes Cancer 43: 390-403, 2005.

24. Kasahara K, Taguchi T, Yamasaki I, Kamada M, Yuri K and Shuin T: Detection of genetic alterations in advanced prostate cancer by comparative genomic hybridization. Cancer Genet Cytogenet 137: 59-63, 2002.

25. Sinclair CS, Adem C, Naderi A, Soderberg CL, Johnson M, Wu K, Wadum L, Couch VL, Sellers TA, Schaid D, Slezak J, Fredericksen Z, Ingle JN, Hartmann L, Jenkins RB and Couch FJ: TBX2 is preferentially amplified in BRCA1- and BRCA2related breast tumors. Cancer Res 62: 3587-3591, 2002.

26. Cai CL, Zhou W, Yang L, Bu L, Qyang Y, Zhang X, Li X, Rosenfeld MG, Chen J and Evans S: T-box genes coordinate regional rates of proliferation and regional specification during cardiogenesis. Development 132: 2475-2487, 2005.

27. Yasuda T, Shirakata M, Iwama A, Ishii A, Ebihara Y, Osawa M, Honda K, Shinohara H, Sudo K, Tsuji K, Nakauchi H, Iwakura Y, Hirai H, Oda H, Yamamoto T and Yamanashi Y: Role of Dok-1 and Dok-2 in myeloid homeostasis and suppression of leukemia. J Exp Med 20: 1681-1687, 2004. 
28. Andersen MH, Becker JC and Straten P: Regulators of apoptosis: suitable targets for immune therapy of cancer. Nat Rev Drug Discov 4: 399-409, 2005.

29. Negishi M, Oinura I and Katoh H: R-Ras as a key player for signaling pathway of plexins. Mol Neurobiol 32: 217-222, 2005.

30. Riefler GM, Balasingam G, Lucas KG, Wang S, Hsu SC and Firestein BL: Exocyst complex subunit sec8 binds to postsynaptic density protein-95 (PSD-95): a novel interaction regulated by cypin (cytosolic PSD-95 interactor). Biochemistry 373: 49-55, 2003.

31. Oberstrass FC, Lee A, Stefl R, Janis M, Chanfreau G and Allain FH: Shape-specific recognition in the structure of the Vts1p SAM domain with RNA. Nat Struct Mol Biol 13: 160-167, 2006.

32. Irrthum A, Devriendt K, Chitayat D, Matthijs G, Glade C, Steijlen PM, Fryns JP, Van Steensel AM and Vikkula M: Mutations in the transcription factor gene SOX18 underlie recessive and dominant forms of hypotrichosis-lymphedematelangiectasia. Am J Hum Genet 72: 1470-1478, 2003.
33. Dallol A, Forgacs E, Martinez A, Sekido Y, Walker R, Kishida T, Rabbitts P, Maher ER, Minna JD and Latif F: Tumour specific promoter region methylation of the human homologue of the Drosophila Roundabout gene DUTT1 (ROBO1) in human cancers. Oncogene 21: 3020-3028, 2002.

34 Tsoukas CD, Grasis JA, Ching KA, Kawakami Y and Kawakami T: Itk/Emt: a link between $\mathrm{T}$ cell antigen receptormediated $\mathrm{Ca}^{2+}$ events and cytoskeletal reorganization. Trends Immunol 22: 17-20, 2001.

35. Levanon EY, Hallegger M, Kinar Y, Shemesh R, DjinovicCarugo K, Rechavi G, Jantsch MF and Eisenberg E: Evolutionarily conserved human targets of adenosine to inosine RNA editing. Nucleic Acids Res 33: 1162-1168, 2005. 